3. Macy, J. T. and Quick, R. E., Transmission and prevention of water-diseases. In Encyclopedia of Life Support System, Eolss Publishers Co Ltd, Oxford, UK, 2009, ISBN: 978-1-84826$182-2$

4. Mena, K. D. and Gerba, C. P., Risk assessment of Pseudomonas bacteria in water. Rev. Environ. Contam. Toxicol., 2009, 201, 71-115.

5. LeChevallier, M. W., Conditions favouring coliform and HPC bacterial growth in drinking water and on water contact surfaces. In Heterotrophic Plate Counts and Drinking-Water Safety, IWA Publishing, London, UK, 2003; http://www.who.int/water sanitation health/dwq/HPC10.pdf

6. Smith, D. P., Cason, J. A., Fletcher, D. L. and Hannah, J. F., Evaluation of carcass scraping to enumerate bacteria on prechill broiler carcasses. Polut. Sci., 2007, 86(7), 1436-1439.

7. Barrel, R. A. E., Hunter, P. R. and Nichols, G., Microbiological standards for water and their relationship to health risk. Commun. Dis. Public Health, 2000, 3(1), 8-13.

8. Majagi, S., Vijaykumar, K., Rajshekhar, M. and Vasanthkumar, B., Chemistry of groundwater in Gulbarga district, Karnataka, India. Environ. Monit. Assess., 2008, 136, 347-354.

9. Groundwater Information Booklet, Gulbarga District, Karnataka South-Western Region, Bangalore, 2012; http://cgwb.gov.in/ District Profile/karnataka/2012/Gulbarga-2012.pdf

10. Chaidez, C., Soto, M., Martinez, C. and Keswick, B., Drinking water microbiological survey of the Northwestern State of Sinaloa, Mexico. J. Water Health, 2008, 6(1), 125-129.

11. Collins, C. H., Lyne, P. M. and Grange, J. M., Microbiological Methods, Oxford University Press Inc, New York, USA, 2004.

12. Atekwanaa, E. A., Atekwanaa, E. A., Roweb, R. S., Werkema, D. D. and Legalld, F. D., The relationship of total dissolved solids measurements to bulk electrical conductivity in an aquifer contaminated with hydrocarbon. J. Appl. Geophys., 2004, 56(4), 281-294.

13. Habuda-Stanic, M., Santo, V, Sikora, M. and Benkotic, S. Microbiological quality of drinking water in public and municipal drinking water supply systems in Osijek-Baranja County, Croatia. Croat. J. Food Sci. Technol., 2013, 5(2), 61-69.

14. Amenu, D., Bacteriological and physicochemical quality of well water sources. Res. J. Chem. Environ. Sci., 2014, 2(5), 13-27.

15. Hunter, P. R., Colford, J. M., LeChevallier, M. W., Binder, S. and Berger, P. S., Waterborne diseases. Emerg. Infect. Dis., 2001, 7(3), 544-545.

16. Al Moosa, M. E., Khan, M. A., Alalami, U. and Husaain, A., Microbiological quality of drinking water from water dispenser machines. Int. J. Environ. Sci. Develop., 2015, 6(9), 710-713.

17. Ashbolt, J. N., Microbial contamination of drinking water and disease outcomes in developing regions. Toxicology, 2004, 198 229-238.

18. Shakya, P., Joshi, T. P., Joshi, D. R. and Bhatta, D. R., Evaluation of physico-chemical and microbiological parameters of drinking water supplied from distribution systems of Kathmandu Municipality. Nepal J. Sci. Technol., 2012, 13(2), 179-184.

19. Medha, A. and Hysko, M., Assessment of water quality of Buna River using microbiological analysis. Albanian J. Agric. Sci. 2014, 13, 113-116

20. Stanwell-Smith, R., Classification of water-related disease. In Encyclopedia of Life Support System, Eolss Publishers Co. Ltd, Oxford, UK, 2009; http://www.eolss.net/sample-chapters/c03/e220a-01-01.pdf

Received 22 May 2018; revised accepted 8 May 2019

doi: $10.18520 / \mathrm{cs} / \mathrm{v} 117 / \mathrm{i} 1 / 114-121$

\section{Production of novel bio-flocculants from Klebsiella variicola BF1 using cassava starch wastewater and its application}

\author{
Ngoc Tuan Nguyen ${ }^{1} *$, Thi Ha My Phan ${ }^{2}$, \\ Tuyet Nhung Tran ${ }^{3}$, Bharath Kumar \\ Velmurugan $^{1}$ and Rudolf Kiefer ${ }^{3}$
}

${ }^{1}$ Toxicology and Biomedicine Research Group, Faculty of Applied Sciences, Ton Duc Thang University, Ho Chi Minh City, Vietnam ${ }^{2}$ Institute of Microbiology and Immunology, National Yang-Ming University, Taipei, Taiwan

${ }^{3}$ Faculty of Applied Sciences, Ton Duc Thang University, Ho Chi Minh City, Vietnam

In this study, Klebsiella variicola BF1 that uses cassava starch wastewater to produce flocculants was identified using 16S rDNA gene sequencing. The pure flocculants of strain BF1 could be easily extracted by ethanol precipitation with a high yield of $7.5 \mathrm{~g} / \mathrm{l}$. It was mainly composed of $83.1 \%$ carbohydrates and $10.6 \%$ proteins. The flocculating activity revealed $97.6 \pm$ $0.6 \%$ for kaolin suspension at $12.8 \mathrm{mg} / \mathrm{l}$ extracted flocculants from strain $\mathrm{BF} 1$ and $2.5 \mathrm{~g} / \mathrm{l} \mathrm{CaCl}$. Interestingly, the flocculating activity was $78 \%$ without the addition of metal ions. Furthermore, flocculants of strain BF1 can be effectively applied in the treatment of cassava starch wastewater and municipal wastewater.

Keywords: Cassava starch, exopolysaccharide, flocculants, Klebsiella variicola, wastewater treatment.

FLOCCULANTS are widely used in industrial processes, including wastewater treatment, textiles, detergents, adhesives and oil recovery ${ }^{1,2}$. Flocculants consist of two main classes: (1) chemical flocculants such as polyacrylamide, polyelectrolytes, polyethyleneimine, polyaluminium chloride and aluminium sulphate, and (2) natural flocculants such as cellulose, microbial flocculants, gelatin, chitosan, gum and mucilage, sodium alginate and tannin ${ }^{1,2}$. The chemical flocculants have been widely used in various applications due to their effectiveness and low cost. However, chemical flocculants can negatively affect ecosystems. Therefore, it is important to replace chemical flocculants by biodegradable flocculants.

Microbial flocculants have attracted research interest ${ }^{3-14}$. Bacteria, fungi and algae are known to be responsible for the production of flocculants ${ }^{4-11,13,14}$. The large-scale production and recovery of bio-flocculants has been studied $^{4-11,13,14}$. Therefore, they are widely applied in many industrial sectors. For the aim of commercialization, a considerable effort has gone into reducing the production cost through using some wastes rich in organic matter,

*For correspondence. (e-mail: nguyenngoctuan@tdtu.edu.vn) 
Table 1. Properties of cassava starch wastewater and municipal wastewater before and after treatment with BP-1

\begin{tabular}{|c|c|c|c|c|c|c|}
\hline \multirow[b]{2}{*}{ Parameters } & \multicolumn{3}{|c|}{ Cassava starch wastewater } & \multicolumn{3}{|c|}{ Municipal wastewater } \\
\hline & $\begin{array}{c}\text { Before } \\
\text { treatment }\end{array}$ & $\begin{array}{c}\text { After } \\
\text { treatment }{ }^{\mathrm{a}}\end{array}$ & $\begin{array}{l}\text { Removal } \\
\text { rate }(\%)\end{array}$ & $\begin{array}{c}\text { Before } \\
\text { treatment }\end{array}$ & $\begin{array}{c}\text { After } \\
\text { treatment }\end{array}$ & $\begin{array}{c}\text { Removal } \\
\text { rate }(\%)\end{array}$ \\
\hline Chemical oxygen demand (COD) (mg/l) & 12,475 & 7,353 & 41.1 & 114 & 46 & 59.6 \\
\hline Biological oxygen demand (BOD) $)_{5}(\mathrm{mg} / \mathrm{l})$ & 8,634 & 4,956 & 42.6 & 87 & 42 & 51.7 \\
\hline Total suspended solids (TSS) (mg/l) & 4,286 & 2,966 & 30.8 & 40 & 26 & 35 \\
\hline Total nitrogen $(\mathrm{mg} / \mathrm{l})$ & 180 & 125 & 30.5 & 17 & 9 & 47.1 \\
\hline Total phosphorous (mg/l) & 34 & 30 & 11.8 & 2 & 1.6 & 20 \\
\hline $\mathrm{OD}_{550}$ & 0.74 & 0.24 & 67.5 & 0.81 & 0.32 & 61.3 \\
\hline $\mathrm{pH}$ & 3.5 & 3.6 & - & 6.8 & 6.8 & - \\
\hline
\end{tabular}

a $500 \mathrm{ml}$ of wastewater is poured into a 1 litre beaker, and $12.8 \mathrm{mg} / 1 \mathrm{BP}-1$ is added to it. Then the solution is stirred for $20 \mathrm{~s}$ and left to stand without shaking for $30 \mathrm{~min}$.

nitrogen and phosphorus. The ability to produce bioflocculants using dairy wastewater, excess sludge, swine wastes, rice stover and potato starch waste has also been reported $^{4,7-9,11-14}$

Cassava (Manihot esculenta Crantz), also called tapio$\mathrm{ca}$, is one of the major staple food crops grown in more than 80 tropical countries. In Vietnam, cassava has quickly changed from a food crop to an industrial crop. The increase in global cassava processing industry has resulted in heavy water pollution, because large amounts of wastewater with extremely high concentrations of organic pollutants are released. These organic pollutants can be used to culture microorganisms for flocculants production. To the best of our knowledge, there has been no report on the flocculants-producing capabilities of microbes using cassava starch wastewater. In this study, bacteria were isolated from municipal wastewater, identified and assessed for their flocculants production using cassava starch wastewater. Utilization of cassava starch wastewater can lower the cost of flocculants production, and further reduce the pollution caused by uncontrolled emission of this type of wastewater. The composition, properties, activity and mechanism of the flocculants were also determined for a better understanding of their potential applications in various industrial processes.

In this study, cassava starch wastewater was taken from household factories in Ho Chi Minh City, Vietnam. Table 1 lists the properties of wastewater.

Bacteria were isolated from samples of Logom canal, Ho Chi Minh City and screened for flocculants production as described below. Sampling sites $\left(10^{\circ} 44^{\prime} \mathrm{N}\right.$, $106^{\circ} 38^{\prime} \mathrm{E}$ ) that are representative of locations receiving water discharged from human activities were selected. In the dry season of 2017 (April), samples (30 cm depth) were collected at three sites. Next, $1 \mathrm{ml}$ of sample was serially diluted with distilled water $\left(10^{1}-10^{5}\right.$ fold), and subsequently, $0.1 \mathrm{ml}$ solution of each dilution was spread on the enrichment medium. The composition of the enrichment medium agar plates is as follows (per liter): beef extract $3 \mathrm{~g}$, peptone $10 \mathrm{~g}, \mathrm{NaCl} 5 \mathrm{~g}$, agar $15 \mathrm{~g}, \mathrm{pH}$ 7.0. The plates were inverted and incubated at $30^{\circ} \mathrm{C}$ for two days. A total 39 morphologically different isolates were obtained and individually inoculated for $24 \mathrm{~h}$ in $5 \mathrm{ml}$ cassava starch wastewater medium. This wastewater medium consists of $\mathrm{KH}_{2} \mathrm{PO}_{4} 2 \mathrm{~g}, \mathrm{~K}_{2} \mathrm{HPO}_{4} 4 \mathrm{~g}, \mathrm{MgSO}_{4} 0.2 \mathrm{~g}, \mathrm{NaCl}$ $0.1 \mathrm{~g}$, urea $2 \mathrm{~g}$ in 1 litre cassava starch wastewater with the $\mathrm{pH}$ value adjusted to 7.0. Strains were incubated at $200 \mathrm{rpm}$ on a rotary shaker at $30^{\circ} \mathrm{C}$, unless otherwise stated.

Cell morphology and Gram staining were observed by phase-contrast microscopy and light microscopy respectively. The 16S rDNA gene of the isolates was amplified by PCR using the primers 27F (5'-AGAGTTTGATCMTGGCTCAG-3') and 1492R (5'-CGGTTACCTTGTTACGACTT- $3^{\prime}$ ). The PCR products were sequenced and consensus sequences were obtained using Bioedit (version 7.2.6). The sequence comparisons using BLAST tool from GenBank were done for identification. The nucleotide sequences of the $16 \mathrm{~S}$ rDNA genes from the isolated strain and the published strains were aligned using Clustal X (version 2.0.3). Using Bootstrap analysis with a default setting of 1000 trials and a seed value of 111, the phylogenetic tree was constructed.

The overnight culture of strain was diluted $1: 50$ in $500 \mathrm{ml}$ fresh cassava starch wastewater medium. The flasks were then incubated for $48 \mathrm{~h}$. The culture broth was collected and centrifuged at $8000 \mathrm{~g}$ for $30 \mathrm{~min}$. The supernatant was subsequently collected and extracted using a modified extraction method as follows. The mixture, including pre-cooled $\left(-20^{\circ} \mathrm{C}\right)$ absolute ethanol and supernatant in the ratio of $2: 1$ was stabilized at $-20^{\circ} \mathrm{C}$ for $24 \mathrm{~h}$. The resultant sediment was centrifuged and dried to produce the crude flocculants. These were dissolved in water, and then Sevage solution (chloroform: $n$-butanol $:: 5: 1$ ) was added to an equal volume ${ }^{3}$. The mixture was then centrifuged at $8000 \mathrm{~g}$ for $30 \mathrm{~min}$ and the pellet was dried, yielding purified flocculants. The total sugar content and protein concentration were determined according to a previous study ${ }^{1}$. A FTIR spectrometer (Bruker's Vertex 79 series FT-IR, Germany) was used to examine the functional groups of flocculants. 
Flocculating efficiency was studied by measuring the turbidity of a kaolin suspension. For this, $9 \mathrm{ml}$ of kaolin suspension $(5 \mathrm{~g} / \mathrm{l}), 1 \mathrm{ml} \mathrm{CaCl}{ }_{2}$ solution $(10 \mathrm{~g} / \mathrm{l})$ and $0.1 \mathrm{ml}$ culture broth or $0.1 \mathrm{mg} / \mathrm{l}$ pure flocculants were mixed vigorously for $20 \mathrm{~s}$ and left to stand without shaking for $5 \mathrm{~min}$. The turbidities of the sample supernatant and a control experiment without flocculants were measured at $550 \mathrm{~nm}$. The flocculating activity can be expressed as follows

Flocculating activity $=(a-b) / a \times 100 \%$,

where $a$ and $b$ are the $\mathrm{OD}_{550}$ values of the control and sample respectively ${ }^{15}$.

To determine the effect of temperature on flocculating activity, flocculants solutions were subjected to different temperature treatments for $30 \mathrm{~min}$. The flocculating activities against kaolin suspension of these treated flocculant solutions were measured. The decrease in the total flocculating activity after the different treatments was used to evaluate the relative contribution of the protein components in the flocculants to their flocculating activity. Metal compounds ( $\mathrm{KCl}, \mathrm{NaCl}, \mathrm{MgSO}_{4}, \mathrm{Fe}_{2} \mathrm{SO}_{4}, \mathrm{FeCl}_{3}$ and $\mathrm{AlCl}_{3}$ ) were added to the mixture instead of $\mathrm{CaCl}_{2}$ in order to determine their effects on the flocculating activity.

The three-level-two-factor central composite design (CCD) was applied to evaluate the most important operating variables $\left(\mathrm{CaCl}_{2}\left(X_{1}\right)\right.$ and the extracted flocculants $\left(X_{2}\right)$ ) in the flocculating process ${ }^{5}$. The ranges of the variables were chosen according to the results of a preliminary experiment as follows: flocculants dosage, 8-18 mg/l and $\mathrm{CaCl}_{2}, 1.5-3.5 \mathrm{~g} / \mathrm{l}$. Thirteen trials were performed with the independent variables at three different levels.

The response variable $(Y)$ was calculated and fitted to a second-order model which contains the independent variables as below

$$
Y=\beta_{0}+\sum \beta_{i} X_{i}+\beta_{i j} X_{i} X_{i}+\sum \beta_{i j} X_{i} X_{j}+\sum \beta_{i i} X_{i}^{2}
$$

where $\beta_{0}, \beta_{\mathrm{i}}$ and $\beta_{i i}$ are the intercept, linear coefficient and quadratic coefficient respectively. $\beta_{i j}$ is a regression coefficient of interaction between the $X_{i}$ and $X_{j}$, whereas $X_{i}$ and $X_{j}$ are input variables that influence the response variable $Y$. For the experimental design, Minitab (version 16.2.4) was applied. The interaction between process variables and responses was performed using the analysis of variance (ANOVA).

To analyse the flocculating efficiency of BP-1 to municipal wastewater and cassava starch wastewater, $500 \mathrm{ml}$ of wastewater was poured into a 1 litre beaker, and $12.8 \mathrm{mg} / \mathrm{l} \mathrm{BP}-1$ was added to it. Then the solution was stirred at $60 \mathrm{rpm}$ for $20 \mathrm{~s}$ and left to stand without shaking for $30 \mathrm{~min}$. The turbidities of the sample super- natant and a control experiment without flocculants were measured at $550 \mathrm{~nm}$. Total suspended solids (TSS), chemical oxygen demand (COD), biological oxygen demand (BOD), total nitrogen and total phosphorus in wastewater and the supernatant of treated wastewater were measured according to the Association of Official Analytical Chemists ${ }^{16}$.

In this study, the $16 \mathrm{~S}$ rDNA gene sequence has been assigned the DDBJ/EMBL/GenBank accession number MH458937.

Thirty-nine morphologically different isolates were selected and checked for their ability to produce high flocculants. However, only nine strains displayed high flocculating efficiency (Table 2). The growth pattern and yield of flocculants of those isolated strains were determined for four days. Among them, a Gram-negative bacterium, namely BF1 produced high flocculants and was selected for further study. The morphological characteristics of the strain include a rod-shaped bacterium without flagella, and size of approximately $0.5 \times 2.5 \mu \mathrm{m}$. The colony of strain BF1 is circular, milky white, smooth and papillary, moist on the surface and not easy to pick up with loops. In order to identify the isolate, $16 \mathrm{~S}$ rDNA gene sequencing was performed. It is closely related to Klebsiella variicola strain DX120E (99\%), originally isolated from sugarcane roots ${ }^{17}$. A phylogenetic neighbour-joining tree based on the nucleotide sequences of $16 \mathrm{~S}$ rDNA genes of strain BF1 and reported flocculantsproducing bacteria was constructed, which revealed that strain BF1 was closely related to flocculants-producing K. pneumonia group with $92 \%$ bootstrap support (Figure 1). Based on the BLAST results, morphological and microscopic characteristics, the pure isolate was classified as $K$. variicola strain BF1.

To optimize the culture conditions for production of flocculants from strain BF1, the effect of temperature, $\mathrm{pH}$, phosphate salts, extra nitrogen source and carbon source was examined. For temperature and $\mathrm{pH}$, the results revealed maximum growth and flocculating rate at $30^{\circ} \mathrm{C}$ and 7.0 respectively. Phosphate salts (at different dosages) were found to be beneficial for cell density and flocculating efficiency in strain BF1 (Figure $2 a$ ). Especially, the flocculating activity improved to $71.4 \%$ when the total added phosphate salts was $6 \mathrm{~g} / \mathrm{l}\left(4 \mathrm{~g} / \mathrm{l}\right.$ of $\mathrm{K}_{2} \mathrm{HPO}_{4}$ and $2 \mathrm{~g} / \mathrm{l} \quad \mathrm{KH}_{2} \mathrm{PO}_{4}$ ). To study the effect of nitrogen sources, beef extract, peptone, yeast extract, urea and $\left(\mathrm{NH}_{4}\right)_{2} \mathrm{SO}_{4}$ were used in the same concentration $(2 \mathrm{~g} / \mathrm{l})$ (Figure $2 b$ ). The flocculating efficiency of five different nitrogen sources ranged from $78.8 \% \pm 1.7 \%$ to $92.7 \% \pm 0.7 \%$. Specifically, peptone, beef extract and urea produced flocculants with the more $90 \%$ efficiency after $24 \mathrm{~h}$ of cultivation. For extra carbon sources (including $2 \mathrm{~g} / \mathrm{l}$ of glucose, maltose, fructose and sucrose and $2 \mathrm{ml} / \mathrm{l}$ of $95 \%$ ethanol), the results were slightly different compared with the culture liquor from cassava starch wastewater medium (Figure $2 c$ ). From these 


\section{RESEARCH COMMUNICATIONS}

Table 2. Screening of flocculants-producing bacterium and its flocculating ratio for kaolin suspension

\begin{tabular}{llcc}
\hline Strain & \multicolumn{1}{c}{ Character morphology } & Gram & $\begin{array}{c}\text { Flocculating } \\
\text { efficiency }(\%)\end{array}$ \\
\hline 2 & Irregular, entire, moist and white & - & $31.4 \pm 4.82$ \\
$5(\mathrm{BF} 1)$ & Circular, entire, moist and milk white & - & $90.0 \pm 2.46$ \\
11 & Irregular, lobate, moist and white & + & $73.8 \pm 5.56$ \\
14 & Irregular, serrate, moist and white & - & $80.7 \pm 3.10$ \\
17 & Circular, lobate, moist and white & - & $86.7 \pm 3.50$ \\
21 & Irregular, entire, moist and milk white & - & $76.4 \pm 3.19$ \\
24 & Circular, serrate, dry and white & - & $85.1 \pm 3.43$ \\
31 & Irregular, entire, moist and white & - & $62.5 \pm 4.26$ \\
38 & Circular, serrate, moist and milk white & $72.7 \pm 9.22$ \\
\hline
\end{tabular}

Each value represents mean $\pm \mathrm{SD}(n=3)$

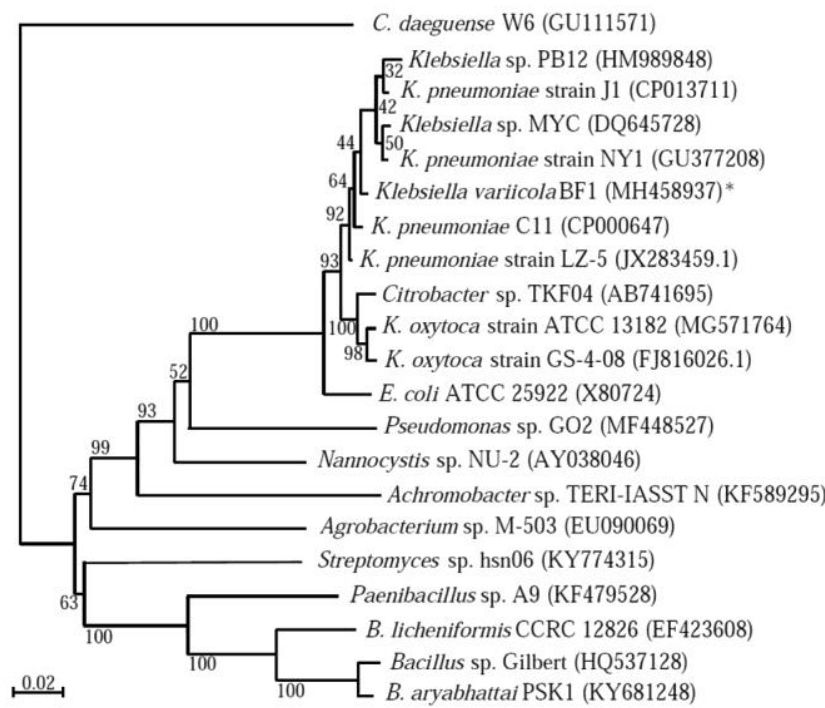

Figure 1. Phylogenetic neighbour-joining trees based on the nucleotide sequences of $16 \mathrm{~S}$ rDNA genes of isolated (indicated by star) and the reported flocculants-producing bacteria. The strains are indicated by their EMBL/GenBank/DDBJ accession numbers after species names. Bootstrap values, indicated at the nodes, are obtained from 1000 bootstrap replicates and are reported as percentages. Bar indicates $2 \%$ sequence divergence.

results, $6 \mathrm{~g} / \mathrm{l}$ phosphate salts and $2 \mathrm{~g} / \mathrm{l}$ urea were chosen for BF1 to produce high flocculating activity at low cost.

Under optimal conditions, the yield of purified BP-1 could reach $7.5 \mathrm{~g} / \mathrm{l}$. The major content of BP-1 was found to be $83.1 \%$ total sugar and $10.6 \%$ protein. The functional group of BP-1 was then analysed using FTIR spectroscopy (Supplementary Figure 1). The infrared spectra of BP-1 showed characteristic functional groups that mainly included carbonyl, amino, and hydroxyl groups and amides.

Figure 3 shows the growth curve of strain BF1 and flocculating activity of its cassava starch wastewater medium. The flocculating rate from early stationary cultures was the highest $(93.5 \%$ at $21 \mathrm{~h})$. At late stationary phase, the flocculating rate started decreasing; this may be due to the de-flocculation enzyme activities. The flocculating activity of untreated BP-1 against kaolin suspension was
$96.18 \% \pm 0.81 \%$. When $\mathrm{BP}-1$ was treated at $100^{\circ} \mathrm{C}$ and $121^{\circ} \mathrm{C}$ for $30 \mathrm{~min}$, flocculating activities were decreased to $75.35 \% \pm 2.66 \%$ and $51.1 \% \pm 4.7 \%$ respectively (Figure $4 a$ ).

Figure 4 shows the effect of BP-1 dosage, $\mathrm{CaCl}_{2}$ concentration and metal ions on the flocculating activity. Flocculating efficiency was more than $80 \%$ for a range of BP-1 dosages (5-50 mg/l); the maximum flocculating activity was observed at an optimal dosage of $13 \mathrm{mg} / \mathrm{l}$ (Figure $4 b$ ). The addition of $\mathrm{K}^{+}, \mathrm{Na}^{+}$or trivalent cations could not evidently enhance the flocculating activity of BP-1. The flocculating activity of BP-1 was slightly enhanced by the addition of bivalent cations, including $\mathrm{Mg}^{2+}, \mathrm{Ca}^{2+}$ and $\mathrm{Fe}^{2+}$ (Figure $4 c$ ). One common trait between $\mathrm{BF} 1$ and the other reported microorganisms is the positive influence of $\mathrm{Ca}^{2+}$ ions in aiding flocculation. Interestingly, the flocculating activity of BP-1 was $78 \%$ without the addition of any cation. As shown in Figure $4 d$, all the flocculating activities were above $89.9 \%$ in the presence of $0.5 \%-4 \% \mathrm{CaCl}_{2}$, in which the optimal dosage was determined to be $2.5 \%$ for flocculation of kaolin solution. BP-1 showed high flocculating efficiency within a wide $\mathrm{pH}$ range. More than $90 \%$ removal rate was observed at either strong acidic or basic $\mathrm{pH}$ range. Flocculating activity of BP-1 was slightly higher in acidic ( $\mathrm{pH}$ below 7) than in basic solution.

The interaction between the dosage of $\mathrm{BP}-1$ and $\mathrm{CaCl}_{2}$ content was studied by three-level-two-factor CCD analysis and response surface methodology (RSM). The fitting polynomial (eq. (2)) was obtained after data fitting. Table 3 shows the predicted and observed flocculating activities (\%).

$$
\begin{aligned}
Y= & 97.45-0.41 X_{1}+1.46 X_{2} \\
& +0.23 X_{1} X_{2}-1.76 X_{1}^{2}-2.14 X_{2}^{2} .
\end{aligned}
$$

ANOVA revealed that the fitted model was statistically valid with high model $F$-values and low $P$ values $(P<0.0001)$. Figure 5 shows the three-dimensional response surface plot. The $\mathrm{CaCl}_{2}$ dosage $(P<0.0001)$ 

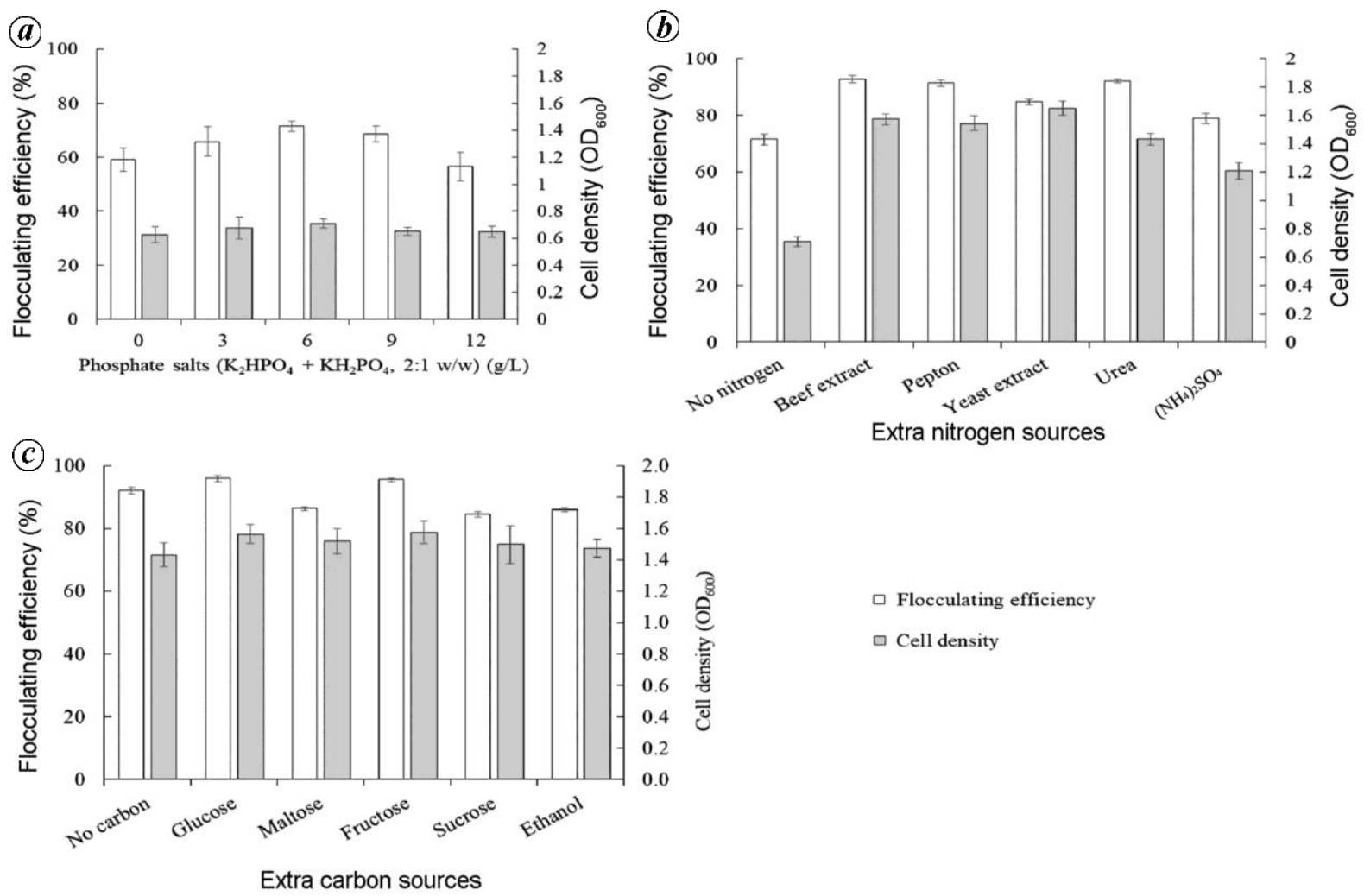

Figure 2. Effects of (a) phosphate salts, $(\boldsymbol{b})$ extra nitrogen sources and $(\boldsymbol{c})$ extra carbon sources on flocculating efficiency and cell density of strain BF1. The medium consists of $(\boldsymbol{a}) \mathrm{MgSO}_{4} 0.2 \mathrm{~g}, \mathrm{NaCl} 0.1 \mathrm{~g}$ and different concentrations of phosphate salts; $(\boldsymbol{b}) \mathrm{K}_{2} \mathrm{HPO}_{4} 4 \mathrm{~g}$, $\mathrm{KH}_{2} \mathrm{PO}_{4} 2 \mathrm{~g}, \mathrm{MgSO}_{4} 0.2 \mathrm{~g}, \mathrm{NaCl} 0.1 \mathrm{~g}$ and $2 \mathrm{~g}$ of different extra nitrogen sources and $(\boldsymbol{c}) \mathrm{K}_{2} \mathrm{HPO}_{4} 4 \mathrm{~g}, \mathrm{KH}_{2} \mathrm{PO}_{4} 2 \mathrm{~g}, \mathrm{MgSO}_{4} 0.2 \mathrm{~g}, \mathrm{NaCl}$ $0.1 \mathrm{~g}$, urea $2 \mathrm{~g}$, and $2 \mathrm{~g}$ of different extra carbon sources in 1 litre cassava starch wastewater with $\mathrm{pH}$ value adjusted to 7.0. Error bars indicate standard deviation of triplicate experiments.

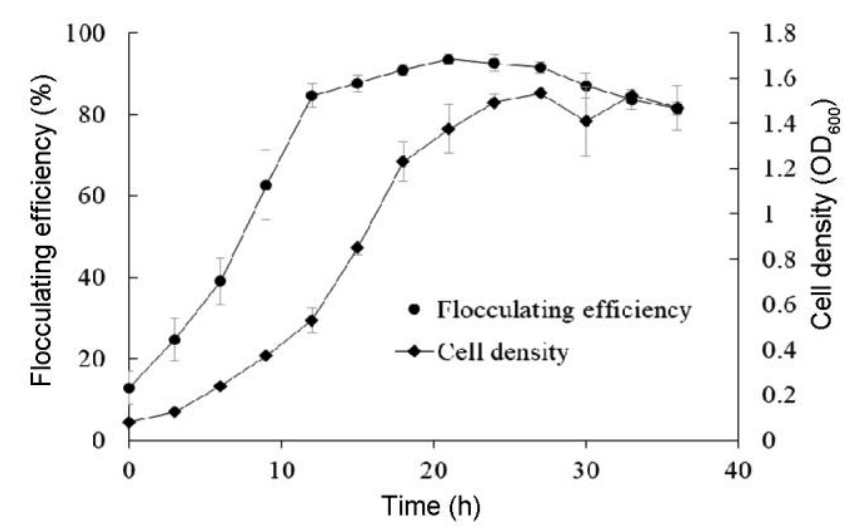

Figure 3. Growth curve of strain BF1 and flocculating activity of its cassava starch wastewater medium. The medium consists of $\mathrm{K}_{2} \mathrm{HPO}_{4}$ $4 \mathrm{~g}, \mathrm{KH}_{2} \mathrm{PO}_{4} 2 \mathrm{~g}, \mathrm{MgSO}_{4} 0.2 \mathrm{~g}, \mathrm{NaCl} 0.1 \mathrm{~g}$, urea $2 \mathrm{~g}$ in 1 litre cassava starch wastewater with $\mathrm{pH}$ value adjusted to 7.0. Error bars indicate standard deviation of triplicate experiments.

exhibited a higher influence than the BP-1 dosage $(P=0.037)$ on the flocculating activity. According to the regression model, the maximum flocculating activity of 97.71\% was obtained under the following conditions: $X_{1}=12.8 \mathrm{mg} / 1$ and $X_{2}=2.67 \mathrm{~g} / \mathrm{l}$. Under optimized condi- tion, the observed flocculating activity was $97.6 \% \pm$ $0.6 \%$. The result closely agrees with the model prediction. Thus, the model is considered to be reliable for describing the effects of $\mathrm{BP}-1$ and $\mathrm{CaCl}_{2}$ dosages on flocculating activity.

In this study, the bonding types in kaolin- $\mathrm{Ca}^{2+}-\mathrm{BP}-1$, kaolin- $\mathrm{Mg}^{2+}-\mathrm{BP}-1$ and kaolin-BP-1 systems were tested by EDTA, EGTA, $\mathrm{HCl}$ and urea treatment. After addition of $3 \mathrm{M} \mathrm{HCl}, 1 \mathrm{M}$ EDTA or $1 \mathrm{M}$ EGTA, the flocculation in three systems did not occur in $30 \mathrm{~min}$ observation. No significant de-flocculation phenomenon was observed in the urea $(3 \mathrm{M})$ added group.

Finally, we determined whether BP-1 flocculants could be used to improve the efficiency of municipal wastewater and cassava starch wastewater treatment. After treatment with $12.8 \mathrm{mg} / \mathrm{BP}-1$, the residual TSS, COD, $\mathrm{BOD}_{5}$, total nitrogen and total phosphorus of cassava starch wastewater and municipal wastewater, were found to be 2996, 7353, 4956, 124 and $30 \mathrm{mg} / \mathrm{l}$ and 26, 46, 42, 9 and $1.6 \mathrm{mg} / \mathrm{l}$ respectively, which were lower than the initial concentrations (Table 1), indicating that the bio-flocculants can be used as an effective pretreatment for cassava starch wastewater and municipal wastewater. 

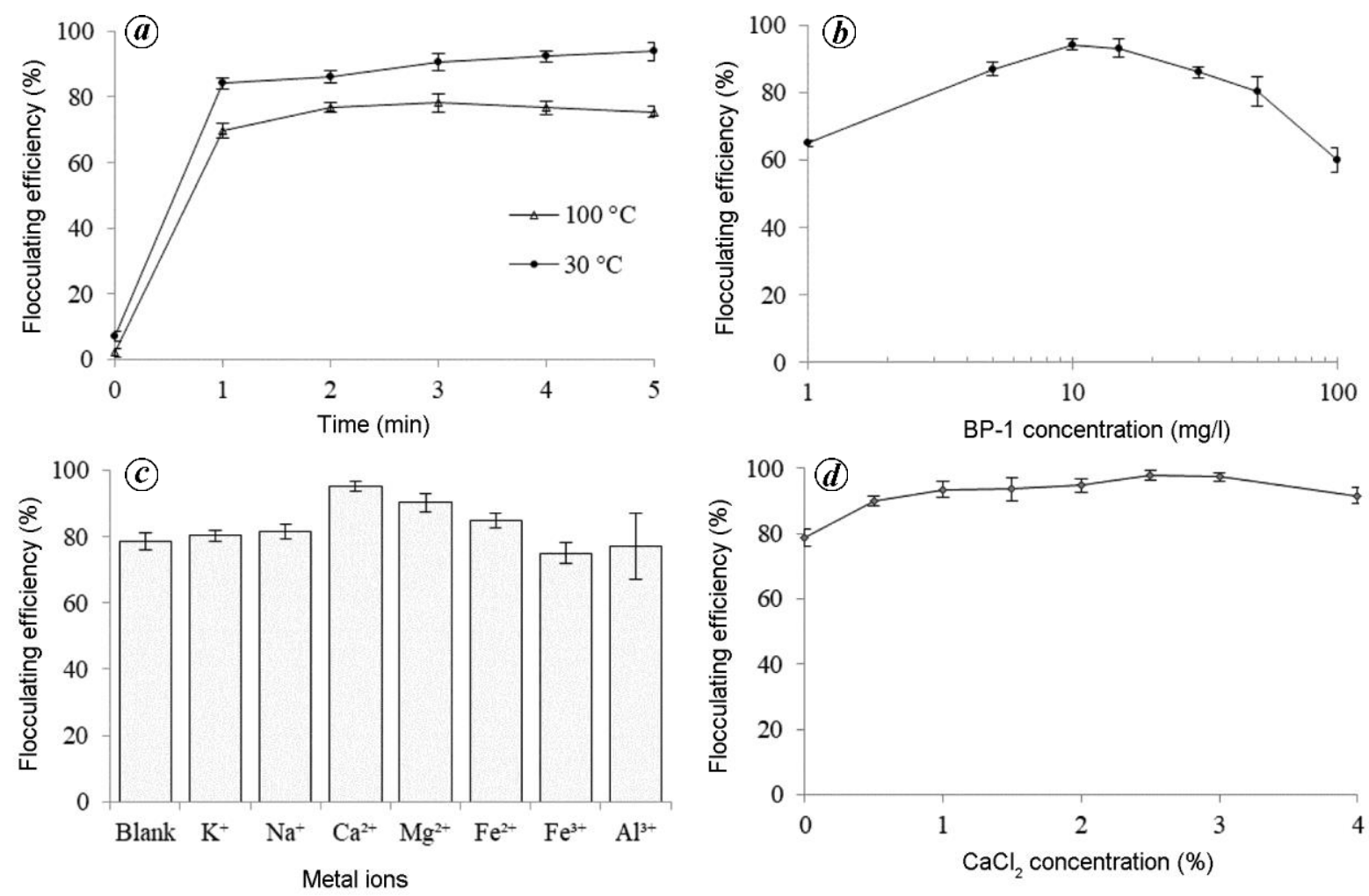

Figure 4. Effects of temperature, $\mathrm{BP}-1$ dosage, $\mathrm{pH}$ and metal ions on flocculating efficiency. $\boldsymbol{a}$, Temperature treatment for $30 \mathrm{~min}, 30 \mathrm{mg} / \mathrm{l} \mathrm{BP}-1$, pH $6.5 ; \boldsymbol{b}$, BP-1 conc. $\mathrm{pH} 6.5,30^{\circ} \mathrm{C} ; \boldsymbol{c}, 10 \mathrm{mg} / 1 \mathrm{BP}-1, \mathrm{pH} 6.5$ and metal ions: $0.1 \mathrm{M}$; $\boldsymbol{d}, 10 \mathrm{mg} / 1 \mathrm{BP}-1$ and $\mathrm{pH}$ 6.5. Error bars indicate standard deviation of triplicate experiments.

Table 3. Central composite design for optimization of the flocculation parameters of kaolin suspension with BP-1

\begin{tabular}{|c|c|c|c|c|c|c|}
\hline \multirow[b]{3}{*}{ Run } & \multicolumn{4}{|c|}{ Factor } & & \\
\hline & \multicolumn{2}{|c|}{ BP-1 } & \multicolumn{2}{|c|}{$\mathrm{CaCl}_{2}$} & \multicolumn{2}{|c|}{ Flocculating efficiency $(\%)$} \\
\hline & $X_{1}$ & $A(\mathrm{mg} / \mathrm{l})$ & $X_{2}$ & $B(\mathrm{~g} / \mathrm{l})$ & Actual value & Predicted value \\
\hline 1 & -1 & 8 & 0 & 2.5 & $95.88 \pm 1.91$ & 96.10 \\
\hline 2 & -1 & 8 & -1 & 1.5 & $92.90 \pm 0.95$ & 92.73 \\
\hline 3 & 0 & 13 & -1 & 1.5 & $93.88 \pm 1.16$ & 93.85 \\
\hline 4 & 0 & 13 & 1 & 3.5 & $97.12 \pm 1.24$ & 96.77 \\
\hline 5 & 0 & 13 & 0 & 2.5 & $97.25 \pm 0.42$ & 97.45 \\
\hline 6 & 0 & 13 & 0 & 2.5 & $97.25 \pm 1.22$ & 97.45 \\
\hline 7 & -1 & 8 & 1 & 3.5 & $95.20 \pm 1.28$ & 95.19 \\
\hline 8 & 1 & 18 & -1 & 1.5 & $91.19 \pm 2.02$ & 91.45 \\
\hline 9 & 1 & 18 & 1 & 3.5 & $94.43 \pm 1.51$ & 94.83 \\
\hline 10 & 1 & 18 & 0 & 2.5 & $95.88 \pm 1.84$ & 95.28 \\
\hline 11 & 0 & 13 & 0 & 2.5 & $97.25 \pm 1.43$ & 97.45 \\
\hline 12 & 0 & 13 & 0 & 2.5 & $97.84 \pm 1.21$ & 97.45 \\
\hline 13 & 0 & 13 & 0 & 2.5 & $97.25 \pm 0.64$ & 97.45 \\
\hline
\end{tabular}

The low production and high cost of bio-flocculants have greatly affected their practical uses; therefore it is necessary to select microorganisms capable of producing high yields of desirable flocculants from low-cost material. Our interests in the characterization of $K$. variicola BF1 stemmed from its ability to produce a high yield of BP-1 using cassava starch wastewater. Table 4 summa- rizes the bio-flocculants producing microorganisms and their properties, including flocculating efficiency, optimum condition for flocculation and characterization of bio-flocculants ${ }^{4-14}$. In general, the genus Klebsiella produces very low yields of its flocculants products, including $K$. oxytoca GS-4-08 (0.2 g/1), Klebsiella sp. S11 (0.9 g/l), Klebsiella sp. PB12 (1.3 g/l), K. pneumoniae 


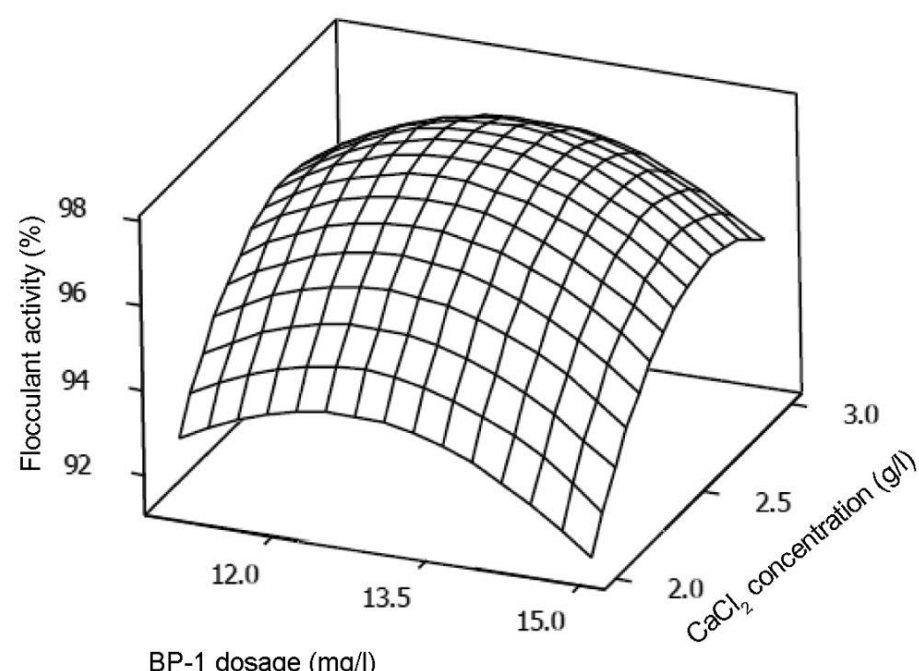

Figure 5. Response surface plots for optimization of flocculating activity.

C11 (1.6 g/l), K. mobilis (2.5 g/l), K. pneumoniae LZ-5 $(2.8 \mathrm{~g} / \mathrm{l}), \mathrm{K}$. pneumoniae $\mathrm{H} 12(3 \mathrm{~g} / \mathrm{l})$ and $K$. variicola B16 $(3.08 \mathrm{~g} / \mathrm{l})^{4-14}$. Interestingly, K. pneumoniae NY1 was reported to show good flocculants production $(14.9 \mathrm{~g} / \mathrm{l})^{18}$. Few strains from other genera reported high yields of flocculants, such as Agrobacterium sp. M-503 $(14.9 \mathrm{~g} / \mathrm{l})^{19}$, Nannocystis sp. NU-2 $\left(14.8 \mathrm{~g} / \mathrm{l}^{20}\right.$, Bacillus licheniformis CCRC $12826\left(14 \mathrm{~g} / \mathrm{l}^{21}\right.$ and Achromobacter sp. TERI-IASST N (ref. 22). In this study, the pure flocculants (BP-1) could be easily extracted from cassava starch wastewater medium by ethanol precipitation with a yield of $7.5 \mathrm{~g} / \mathrm{l}$. Compared to strains which were isolated from river water or wastewater, strain BF1 revealed 5.8and 36-fold higher yield than Klebsiella sp. PB12 (ref. 7) and Citrobacter sp. TKF04 (ref. 23) respectively, in producing pure flocculants.

The flocculating activity was found to be $97.6 \% \pm$ $0.6 \%$ for kaolin suspension with $12.8 \mathrm{mg} / \mathrm{l} \mathrm{BP}-1$ and $2.5 \mathrm{~g} / \mathrm{C} \mathrm{CaCl}_{2}$. The flocculating activity of BP-1 was $78 \%$, without the addition of metal ions. Mandal et al. ${ }^{7}$ reported that flocculating activity of the bio-flocculants produced by Klebsiella sp. PB 12 could reach $98 \%$ for kaolin suspension with $17 \mathrm{mg} / \mathrm{l} \mathrm{EPS}$ and $4 \mathrm{mM} \mathrm{CaCl}_{2}$. However, in the absence of $\mathrm{Ca}^{2+}$ ions, no effective flocculation was observed which indicates the requirement of $\mathrm{CaCl}_{2}$ for effective flocculation by forming $\mathrm{Ca}^{2+}$-mediated complexes of EPS and kaolin. There are only few studies reporting high flocculating activity with or without $\mathrm{Ca}^{2+}$ ions, in which flocculants produced by $K$. pneumoniae strain YZ-6 and LZ-5 showed $96.5 \%$ and $98 \%$ activity with $\mathrm{Ca}^{2+}$ ions for kaolin suspension at 50 and $54.3 \mathrm{mg} / \mathrm{l}$ EPS respectively ${ }^{6,8}$. In the absence of $\mathrm{Ca}^{2+}$ ions, flocculants produced by both strains still reached $80 \%$ efficiency. This is in agreement with our results, but the required dose of BP-1 is much lower, suggesting its potential industrial use.
Compositions of bio-flocculants are often reported to be glycoprotein-like substances, where the conjugates play an important role in exhibiting flocculating activities $^{24-26}$. Interestingly, some studies report the absence of proteins in bio-flocculants, that indicates the important role of polysaccharides in flocculation ${ }^{15}$. In this study, FTIR analysis of BP-1 revealed the presence of $-\mathrm{OH}$ or -NH groups, in which the broad spectra appeared to be similar to that of a sugar-protein complex. In addition, the major contents of BP-1 were found to be $83.1 \%$ total sugar and $10.6 \%$ protein. These results are in disagreement with previous studies (Table 4).

The coordination of flocculants with kaolin and metal ions was examined for the flocculation mechanism of BP1. The positive influence of $\mathrm{Ca}^{2+}$ and $\mathrm{Mg}^{2+}$ ions on flocculating efficiency was recognized. Therefore, the bonding types in kaolin- $\mathrm{Ca}^{2+}-\mathrm{BP}-1$, kaolin- $\mathrm{Mg}^{2+}-\mathrm{BP}-1$ and kaolin-BP-1 systems were tested by EDTA, EGTA, HCl and urea treatment. Urea is known to disrupt hydrogen bonds, while $\mathrm{HCl}$ destroys the ionic bonds ${ }^{27}$. No significant de-flocculation phenomenon after addition of $3 \mathrm{M}$ urea was observed, suggesting that hydrogen bonds do not exist predominantly in BP-1. After the addition of $3 \mathrm{M} \mathrm{HCl}$, the cloudy kaolin- $-\mathrm{Ca}^{2+}-\mathrm{BP}-1$, kaolin $-\mathrm{Mg}^{2+}$ BP-1 and kaolin-BP-1 systems did not occur in $30 \mathrm{~min}$ observation, suggesting the role of ionic bonds in these systems. To further study the role of $\mathrm{Ca}^{2+}$ and $\mathrm{Mg}^{2+}$ ions in the systems, $1 \mathrm{M}$ EDTA and $1 \mathrm{M}$ EGTA were added. EDTA and EGTA are well known as chelating agents, in which EGTA has a higher affinity for $\mathrm{Ca}^{2+}$ but a lower affinity for $\mathrm{Mg}^{2+}$ compared to EDTA ${ }^{27}$. Interestingly, our results revealed that all systems are sensitive to EDTA or EGTA; this might be because the chelating agents have high affinity to $\mathrm{Ca}^{2+}$ and $\mathrm{Mg}^{2+}$ ions, and also to BP-1 flocculants. This can be explained by the fact that high concentration of EDTA, EGTA and $\mathrm{HCl}$ affects the 


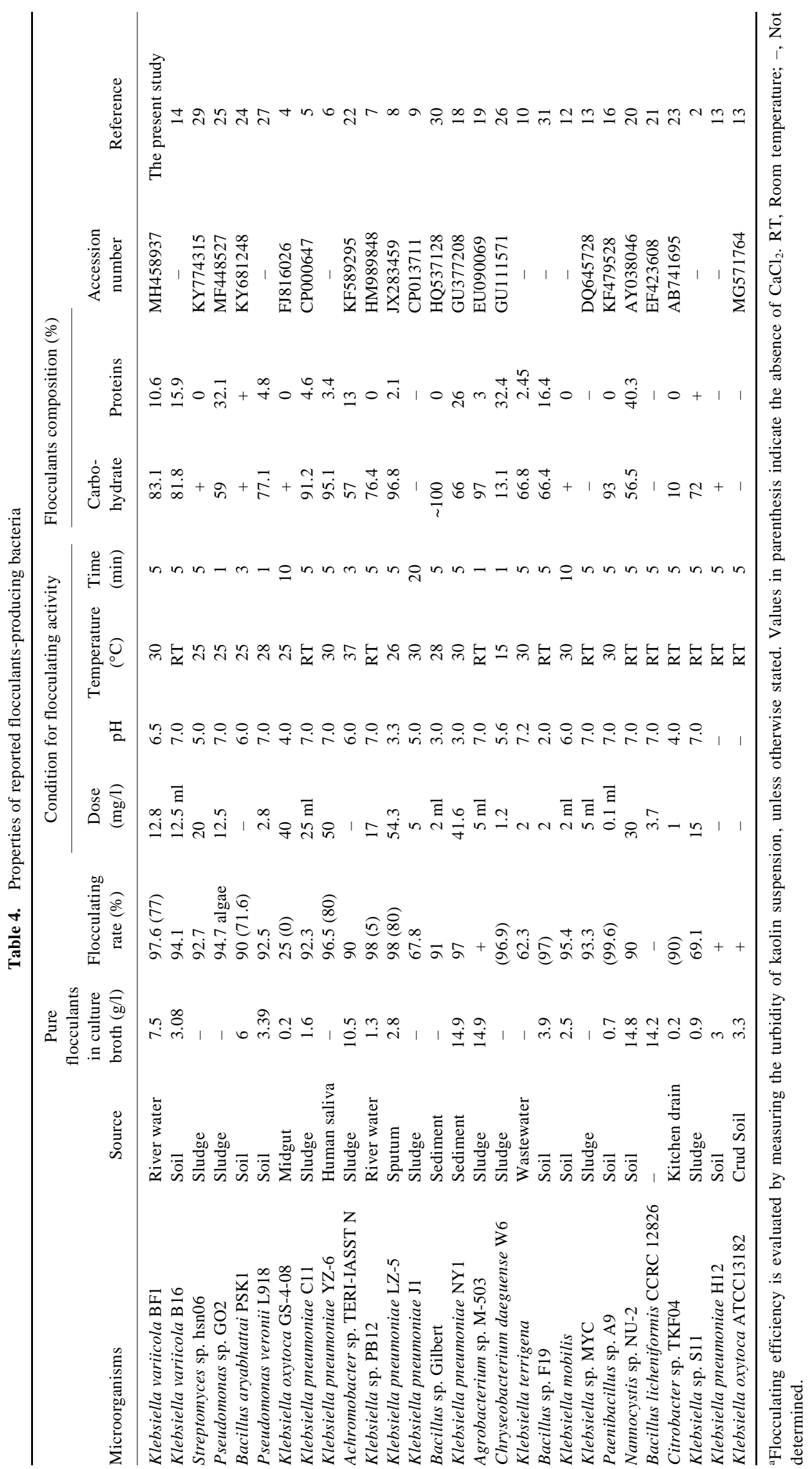




\section{RESEARCH COMMUNICATIONS}

stability of the protein components, or disrupts the interaction between the proteins and polysaccharides. This reconfirms that the protein is one of the major flocculating components in BP-1. In previous studies, some proteins or polysaccharides with high molecular weight have been reported as adhesions, which can promote the cells initial attachment of the cells on the solid surface to form biofilms ${ }^{28}$. Therefore, the flocculation of BP-1 may be achieved by adhesion mechanism, in which the proteins or polysaccharides can attach on the surface directly and bridge the kaolin clay particles, and thus promote their flocculation.

1. Buthelezi, S. P., Olaniran, A. O. and Pillay, B., Production and characterization of bioflocculants from bacteria isolated from wastewater treatment plant in South Africa. Biotechnol. Bioprocess Eng., 2010, 15, 874-881.

2. Dermlim, W., Prasertsan, P. and Doelle, H., Screening and characterization of bioflocculant produced by isolated Klebsiella sp. Appl. Microbiol. Biotechnol., 1999, 52, 698-703.

3. Sun, P., Hui, C., Bai, N., Yang, S., Wan, L., Zhang, Q. and Zhao, Y., Revealing the characteristics of a novel bioflocculant and its flocculation performance in Microcystis aeruginosa removal. Sci. Rep., 2015, 5, 17465.

4. Yu, L. et al., A novel Fe(III) dependent bioflocculant from Klebsiella oxytoca GS-4-08: culture conditions optimization and flocculation mechanism. Sci. Rep., 2016, 6, 34980.

5. Liu, J. W., Ma, J. W., Liu, Y. Z., Yang, Y., Yue, D. B. and Wang, H. T., Optimized cultivation of a bioflocculant M-C11 produced by Klebsiella pneumoniae and its application in sludge dewatering. Huan jing ke xue=Huanjing kexue, 2014, 35, 1183-1190.

6. Luo, Z., Chen, L., Chen, C., Zhang, W., Liu, M., Han, Y. and Zhou, J., Production and characteristics of a bioflocculant by Klebsiella pneumoniae YZ-6 isolated from human saliva. Appl. Biochem. Biotechnol., 2014, 172, 1282-1292.

7. Mandal, A. K., Yadav, K. K., Sen, I. K., Kumar, A., Chakraborti, S., Islam, S. S. and Chakraborty, R., Partial characterization and flocculating behavior of an exopolysaccharide produced in nutrient-poor medium by a facultative oligotroph Klebsiella sp. PB12. J. Biosci. Bioeng., 2013, 115, 76-81.

8. Zhao, H., Liu, H. and Zhou, J., Characterization of a bioflocculant MBF-5 by Klebsiella pneumoniae and its application in acanthmoeba cysts removal. Bioresour. Technol., 2013, 137, 226-232.

9. Xing, J., Yang, J. X., Li, A., Ma, F., Liu, K. X., Wu, D. and Wei, W., Removal efficiency and mechanism of sulfamethoxazole in aqueous solution by bioflocculant MFX. J. Anal. Meth. Chem., 2013, 2013, 568614.

10. Ghosh, M., Pathak, S. and Ganguli, A., Effective removal of cryptosporidium by a novel bioflocculant. Water Environ. Res., 2009, 81, 160-164.

11. Wang, S. G., Gong, W. X., Liu, X. W., Tian, L., Yue, Q. Y. and Gao, Q. Y., Production of a novel bioflocculant by culture of Klebsiella mobilis using dairy wastewater. Biochem. Eng. J., 2007, 36, 15.

12. Yue, L., Ma, C. and Chi, Z., Bioflocculant produced by Klebsiella sp. MYC and its application in the treatment of oil-field produced water. J. Ocean Univ. China, 2006, 5, 333-338.

13. Nakata, K. and Kurane, R., Production of an extracellular polysaccharide bioflocculant by Klebsiella pneumoniae. Biosci., Biotechnol. Biochem., 1999, 63, 2064-2068.

14. Xia, X., Liang, Y., Lan, S., Li, X., Xie, Y. and Yuan, W., Production and flocculating properties of a compound biopolymer flocculant from corn ethanol wastewater. Bioresour. Technol., 2018, 247, 924-929.
15. Deng, S. B., Bai, R. B., Hu, X. M. and Luo, Q., Characteristics of a bioflocculant produced by Bacillus mucilaginosus and its use in starch wastewater treatment. Appl. Microbiol. Biotechnol., 2003, 60, 588-593.

16. AOAC Official Methods of Analysis, Association of Official Analytical Chemists, Arlington, 1990, 15th edn.

17. Lin, L. et al., Complete genome sequence of endophytic nitrogenfixing Klebsiella variicola strain DX120E. Stand. Genomic Sci., 2015, 10, 22.

18. Nie, M. et al., Production of a novel bioflocculant MNXY1 by Klebsiella pneumoniae strain NY1 and application in precipitation of cyanobacteria and municipal wastewater treatment. J. Appl. Microbiol., 2011, 111, 547-558.

19. Li, Q., Liu, H. L., Qi, Q. S., Wang, F. S. and Zhang, Y. Z., Isolation and characterization of temperature and alkaline stable bioflocculant from Agrobacterium sp. M-503. New Biotechnol., 2010, 27, 789-794.

20. Zhang, J., Liu, Z., Wang, S. and Jiang, P., Characterization of a bioflocculant produced by the marine myxobacterium Nannocystis sp. NU-2. Appl. Microbiol. Biotechnol., 2002, 59, 517-522.

21. Shih, I. L., Van, Y. T., Yeh, L. C., Lin, H. G. and Chang, Y. N., Production of a biopolymer flocculant from Bacillus licheniformis and its flocculation properties. Bioresour. Technol., 2001, 78, 267-272.

22. Subudhi, S., Batta, N., Pathak, M., Bisht, V., Devi, A., Lal, B. and Alkhulifah, B., Bioflocculant production and biosorption of zinc and lead by a novel bacterial species, Achromobacter sp. TERIIASST N, isolated from oil refinery waste. Chemosphere, 2014, 113, 116-124.

23. Fujita, M., Ike, M., Tachibana, S., Kitada, G., Kim, S. M. and Inoue, Z., Characterization of a bioflocculant produced by Citrobacter sp. TKF04 from acetic and propionic acids. J. Biosci. Bioeng., 2000, 89, 40-46.

24. El-Salam, A. E., Abd-El-Haleem, D., Youssef, A. S., Zaki, S., Abu-Elreesh, G. and El-Assar, S. A., Isolation, characterization, optimization, immobilization and batch fermentation of bioflocculant produced by Bacillus aryabhattai strain PSK1. J. Genet. Eng. Biotechnol., 2017, 15, 335-344.

25. Guo, H., Hong, C., Zheng, B., Lu, F., Jiang, D. and Qin, W., Bioflocculants' production in a biomass-degrading bacterium using untreated corn stover as carbon source and use of bioflocculants for microalgae harvest. Biotechnol. Biofuels, 2017, 10, 306.

26. Liu, W., Wang, K., Li, B., Yuan, H. and Yang, J., Production and characterization of an intracellular bioflocculant by Chryseobacterium daeguense W6 cultured in low nutrition medium. Bioresour. Technol., 2010, 101, 1044-1048.

27. Guo, J., Yang, C. and Peng, L., Preparation and characteristics of bacterial polymer using pre-treated sludge from swine wastewater treatment plant. Bioresour. Technol., 2014, 152, 490-498.

28. Liu, W. J., Yuan, H. L. and Yang, J. S., The mechanism of kaolin clay flocculation by a cation-independent bioflocculant produced by Chryseobacterium daeguense W6. AIMS Environ. Sci., 2015, 2, 169-179.

29. Li, Y., Xu, Y., Zheng, T. and Wang, H., Flocculation mechanism of the actinomycete Streptomyces sp. Hsn06 on chlorella vulgaris. Bioresour. Technol., 2017, 239, 137-143.

30. Nontembiso, P., Sekelwa, C., Leonard, M. V. and Anthony, O. I., Assessment of bioflocculant production by Bacillus sp. Gilbert, a marine bacterium isolated from the bottom sediment of algoa bay. Marine Drugs, 2011, 9, 1232-1242.

31. Zheng, Y., Ye, Z. L., Fang, X. L., Li, Y. H. and Cai, W. M., Production and characteristics of a bioflocculant produced by Bacillus sp. F19. Bioresour. Technol., 2008, 99, 7686-7691.

Received 2 December 2018; revised accepted 29 April 2019

doi: $10.18520 / \mathrm{cs} / \mathrm{v} 117 / \mathrm{i} 1 / 121-129$ 